\title{
Online Game Addiction and Gen Z: A Comparative Study on Turkish and Romanian High School Students
}

\section{Huri Deniz Karcı, Bahar Urhan}

\begin{abstract}
As being among "the digital natives" of the technology era, Generation Z and their online behaviors are important subjects to study in depth. Surrounded by technology, Generation $\mathrm{Z}$ is easily getting and using all technology products, and they do not feel any constraint about spending time with them, which might lead to a kind of addiction. The study was designed to examine the two-factor solution of online gaming addiction by Faraci and her colleagues' internet addiction version employing the IAT of 20 items by Young. In order to reveal the present state, two field studies in two high schools from Turkey and Romania were run comparatively. Turkish and Romanian participants replied the 20-item-IAT and the questionnaire about online gaming behavior via an online survey platform. To determine the dimensions of online gaming addiction exploratory factor analysis and confirmatory factor analysis are performed. Reliability coefficients of both factors were satisfactory. According to confirmatory factor analysis goodness-of-fit indexes in both samples were reasonable. In conclusion, both factors fit well into the present study producing some other results about online gaming behavior, as well.
\end{abstract}

Key words: Online Gaming, Addiction, Generation Z, The Internet, Online Gaming Behavior

$\begin{array}{ll}\text { HURI DENIZ KARCI } & \text { BAHAR URHAN } \\ \text { Asst. Prof. } & \text { Assoc. Prof. } \\ \text { Ankara Medipol University } & \text { Akdeniz University } \\ \text { denizkarci84@gmail.com } & \text { baharurhan@akdeniz.edu.tr } \\ \text { ORCID ID: 0000-0003-1544-8249 } & \text { ORCID ID: 0000-0001-5559-9311 }\end{array}$

SELÇUK ILETIŞIM DERGISI 2021; 14(2): 549-575

doi: 10.18094/ JOSC.811992

Geliş Tarihi: 17.10.2020 Kabul Tarihi: 01.04.2021 Yayın Tarihi: 25.04.2021 


\section{Çevrimiçi Oyun Bağımlılığı ve Z \\ Kuşağı: Türk ve Romanyalı Lise \\ Öğrencileri Üzerine Karşılaştırmalı \\ Bir Çalışma}

SELÇUK ILETIŞIM

DERGISI 2021;

14(2): 549-575

doi: 10.18094/ JOSC.811992

\section{Huri Deniz Karcı, Bahar Urhan}

\section{ÖZ}

Teknoloji çağının "dijital yerliler" adı verilenleri arasında yer alan Z Kuşağı ve onların çevrimiçi davranışları, derinlemesine çalışılması gereken önemli konulardır. Teknoloji ile kuşatılmış olan Z Kuşă̆ı, tüm teknoloji ürünlerini kolayca elde etmekte, kullanmakta ve onlarla zaman geçirme konusunda herhangi bir kısıtlama hissetmemektedir, bu da bir tür bağımlıı̆a yol açabilmektedir. Bu çalışma, Faraci ve meslektaşlarının Young tarafından hazırlanan versiyonu olan 20 maddelik IAT'yi kullanarak internet ve çevrimiçi oyun bağımlılığının iki faktörlü çözümünü incelemek üzere tasarlanmış̧ır. Mevcut durumu ortaya çıkarmak için Türkiye ve Romanya'dan iki lisede karşılaştırmalı olarak eşzamanlı iki saha çalışması yapıımıştı. Türk ve Romanyalı katııımcılar, çevrimiçi oyun davranışı hakkındaki ankete bir çevrimiçi anket platformu aracılı̆ı̆yla yanıt vermişlerdir Çevrimiçi oyun bağımlıı̆ı̆ın boyutlarını belirlemek için açımlayııı faktör analizi ve doğrulayııı faktör analizi yapılmışıı. Her iki faktörün güvenilirlik katsayıları tatmin edici olduğu görülmüştür. Doğrulayııı faktör analizine göre her iki örneklemdeki uyum iyiliği indeksleri makul bulunmuştur. Sonuç olarak, her iki faktör de mevcut araştırmaya tam olarak uymaktadır ve çalışma çevrimiçi oyun davranışı hakkında başka sonuçlar da vermektedir.

Anahtar kelimeler: Çevrimiç̧i Oyun, Bağımlılık, Z Kuşağı, İnternet, Çevrimiç̧i Oyun Davranışı

$\begin{array}{ll}\text { HURi DENiZ KARCI } & \text { BAHAR URHAN } \\ \text { Dr. Öğr. Üyesi } & \text { Doç.Dr. } \\ \text { Ankara Medipol Üniversitesi } & \text { Akdeniz Üniversitesi } \\ \text { denizkarci84@gmail.com } & \text { baharurhan@akdeniz.edu.tr } \\ \text { ORCID ID: 0000-0003-1544-8249 } & \text { ORCID ID: 0000-0001-5559-9311 }\end{array}$

JOURNAL OF SELÇUK COMMUNICATION 2021; 14(2): 549-575

doi: 10.18094/ JOSC.811992
$[3]$

SEELFIIX

ILETISTM

doi: $10.18094 / \mathrm{J} 0 \mathrm{sC} .811992$ 


\section{INTRODUCTION}

Playing games is the primary way of learning something in human life. People play games beginning from their early ages and discover the world. Online games are designed to satisfy the need for playing games that feed the human brain. These games were being thought as innocent and useful, and they seemed as serving to complete a task about playing need of those who have to live in flats. But in the last decades, these games have had a huge marketing share. So, producers want to design these games as being an inseparable part of human life. They seem to have succeeded in this target of being essential in adolescents' life. And also, as a result of Generation Z's nature, and their way of thinking, online games are likely to have a very long-life span.

Different generations have different behavioral characteristics that are widely influenced by their surroundings. So behavioral characteristic development of Generation Z is significantly shaped and influenced by different and up-to-date contexts and surroundings. They grow up along with a highly sophisticated technological environment that made them likely much more expertly use of media and all technological products compared to their predecessor (Mat Saleh, Mahbob, \& Baharudin, 2017).

As a result of technology everywhere and young people's interactions with it, today's students' way of thinking and knowledge processing are different compared to before. As said Dr. Bruce D. Berry of Baylor Medical School: "Different kinds of experiences lead to different brain structures.". The new generation's brain is physically changing and differs from their parents as a result of how they grow. The most useful name for these new students of today is "Digital Natives". The mother tongue of today's students is the same as the digital language of computers, video games, and the Internet (Prensky, 2001). Although Prensky's theory about today's children is denied by some authorities, we agree that these children should be considered as strangers and well-studied in order to keep them safe from new and unpredictable dangers. By having different thinking style and brain structure, Generation Z can think the online games as not harmful as their elders see. They generally feel confident about what they are doing, and it can be hard to convince them and protect from negative stimuli. So, it is important to discover their way of thinking to guide their relationship with technology. 


\section{THE RELATIONSHIP BETWEEN GENERATION Z AND TECHNOLOGY}

Once a particular generation's zeitgeist becomes clear in response to the major societal event then so do the dates bracketing the generations (Rickes, 2016). Although the authors disagree with the date of birth of Generation Z, there is consensus that Generation Z was born between 1995 and 2012. As the literature continues to emerge in exact dates of this group, it can be corrected. The inevitable effect of technology on Generation Z has led these enthusiastic consumers of digital technology to rely on it for knowledge and interaction (Seemiller \& Grace, 2016; Twenge, 2017). As a result, Generation Z exhibits less developed social skills, and the need for technology places them in isolation, insecurity, depression, and other mental health risks. Positively, Generation Z represents an open-minded population that is satisfied with the differences. The beginning of this generation, 1995, coincides with the time in which the World Wide Web became public. Generation Z is called iGen, Net Generation, iGeneration, Gene Next, Gen Tech, GenWii, Post Gen etc. There is no consensus on the transitional date between the generation called Millennials and Generation Z. But comparing with the Millennials that are known to be curious about technological innovations, Generation $\mathrm{Z}$ is the real digital natives because they do not know the times without the Internet (Rickes, 2016; Seemiller \& Grace, 2016). For example, according to Twenge, Generation Z is addicted to their smartphones. Even if they can evaluate and say that they know the danger of spending over-time via their technological devices, they think that they cannot have an ordinary life without digital media (2017).

There are several common characteristics of Generation Z. According to the findings of the studies conducted with 1,200 Generation Z students in the United States, individuals of Generation Z:

- Describe themselves as effective, thoughtful, loyal, compassionate, open-minded, and responsible.

- Receive the message that Generation Z'ers should be entrepreneurs, so they adapt their mentality according to that.

- See the most important issues that deserve attention: Education, employment, and racial equality.

- Often do not deal with political issues and pays little attention to work in public service, preferring not to participate because of seeing political systems as dysfunctional. 
- Are career-oriented because Generation Z'ers say that adults around them have lost their jobs and experience house foreclosures.

- Are aware of the troubles and traumas that occur not only in the lives of family members and friends but also the problems of all the communities in the world.

- Want to have a thoughtful world view and to join the service to have a tangible and lasting impact on systematic and structural problems.

- Are focused on the understanding of "We", and often motivated by the desire to help others and to be satisfied. Generation Z'ers want to advocate and work for something they believe.

- Are willing to take personal risks when Generation Z'ers believe they will achieve more gain (Loveland, 2017).

In the light of these characteristics, Generation Z'ers seem to take their own responsibility about crucial issues. They often appeal to their logic while they are pursuing their life. So, they should be logically convinced about the harms of online games, or online games should be served to them as an education tool.

\section{INTERNET AND GAME ADDICTION}

Internet addiction definition was made by DSM-IV in 2010 as a similar pattern to pathological gambling and substance abuse defined in its previous editions (Young, 1998) (Widyanto \& McMurran, 2004). Next, the definition of video gaming addiction was made by American Psychiatric Association in DSM_V. (Ferguson, Coulson, \& Barnett, 2011; van Rooji, Schoenmakers, Vermulst, van den Eijnden, \& van de Mheen, 2010; Blinka, 2015). In 2017, Turkish Green Crescent hosted Effects of Addiction Behaviors on Public Health meeting with the participation of World Health Organization (WHO). In this context, Online Game Addiction was declared as a mental health problem/behavior disorder by WHO in the ICD11 (International Classification of Diseases) (World Health Organization, 2018; The Green Crescent, 2018). According to the declaration: "Gaming disorder is characterized by a pattern of persistent or recurrent gaming behavior ('digital gaming' or 'video-gaming'), which may be online (i.e., over the Internet) or offline, manifested by: 1) impaired control over gaming (e.g., onset, frequency, intensity, duration, termination, context); 2) increasing priority given to gaming to the extent that gaming takes precedence over other life interests and daily activities; and 3) continuation or escalation of gaming 
despite the occurrence of negative consequences. The behavior pattern is of sufficient severity to result in significant impairment in personal, family, social, educational, occupational, or other important areas of functioning. The pattern of gaming behavior may be continuous or episodic and recurrent. The gaming behavior and other features are normally evident over a period of at least 12 months for a diagnosis to be assigned, although the required duration may be shortened if all diagnostic requirements are met, and symptoms are severe." (World Health Organization, 2018). Such gaming behaviors and features could result in gaming addiction. Many Generation Z members can be emotionally and cognitively preoccupied with online gaming; even more, they can lose their control and be interfered with daily life as Faraci et.al.'s study (2013) indicated.

Although playing online games provides the adolescents some technical skills about their way of thinking, playing them in unrestrained circumstances may lead to some serious mental health issues. To benefit from those digital games, some precautions should be taken by families or even by the government. There should be some filters about online game genres and could be applied some restraints about the duration of spending time with online games.

There have been a lot of studies on the overuse of the Internet, online life of youth, and online gaming addiction, their effects, and consequences. According to the results of these studies; "there is a positive relationship between depression risk and Internet addiction" (Öner \& Arslantaş, 2018), the students who spend their time with sports activities were found as being less addicted to the digital games, income level is very important on addiction because the students who have a good income can access to digital tools easier than the ones haven't. There is also a significant finding in a recent study comparing with the dominant results about the gender of the players that female students have found more addicted to online games than males (Ekinci, Ilimdar, Özer, \& Kara, 2017). Some other significant psychological consequences were revealed by the studies. According to these, lacking control and neglecting social life was found to be associated with high Internet use (Widyanto \& McMurran, 2004).

A recent study has shown that almost every one of five Romanian adolescents may have Internet Gaming Disorder (IGD) symptoms, and permissive parenting style may affect these symptoms. The extreme occupancy with Internet gaming is similar in girls and boys (Maftei \& Enea, 2020). In some research, important psychological and clinical results are found; routine Internet use and playing games 
can affect human brain structure and function. For example, a structural and functional effect in specific fields of brain have seen that mediate the dopamine award (Weinstein, Livny, \& Weizman, 2017). Specifically, studies based on the Internet Addiction Test (IAT) by Young became more of an issue for the present study since different results could be depicted in different parts of the world. Different versions of the test were tried concluding different factors:

Widyanto \& McMurran (2004) used Young's test in their study to expand and examine systematically adding 15 more questions to the questionnaire regarding demographic information and Internet usage. The study resulted in six factors - salience, excessive use, neglecting work, anticipation, lack of control, neglecting social life. (Çavuş, Ayhan, \& Tuncer, 2016) used the IAT to examine the computer game addiction of the university youth in the sample of Aksaray University. They concluded the study with four factors - negligence, having feeling of deprivation, not quiting gaming, preferring gaming to other activities- and used some other questions regarding computer gaming - game kinds, meaning of playing games, gaming platforms, average playing hours, education level of mother and father and monthly income. Faraci et al. (2013) employed the IAT to evaluate the psychometric properties of the Italian version of the test, specifically testing the factor structure stability across cultures. They resulted the test in two major factors - emotional and cognitive preoccupation with the internet and loss of control and interference with daily life. Indeed, the result of two factors was based on (Barke, Nyenhuis, \& KrönerHerwig, 2014) German version of the Internet addiction test: a validation study, in which they assessed cognitive behavioral aspects of problematic Internet use.

\section{METHODS}

Stemming from Faraci et al.'s (2013) two-factor-solution for the IAT suggestion in a crosscultural study and Cavus et al.'s (2016) using the Internet test in computer gaming and questions regarding computer gaming behavior, we conducted the present study to examine two-factor-solution of the IAT in online gaming addiction as a cross-cultural study comparing Turkish and Romanian Generation Z members. Indeed, Faraci et al. (2013) aimed at constructing dimensionality of the IAT in terms of psychometric properties in Internet addiction. Finally, we aimed at evaluating the two-factor solution and its psychological context within the framework of online gaming addiction comparing Generation Z students in two different cultures. 
In the present study we expect to find comparatively in both cultures:

1. Two-factor-solution of the IAT, emotional and cognitive preoccupation with Internet and loss of control and interference with daily life, is consistent with online gaming addiction in the present study.

Then:

2. Whether online gaming addiction dimensions indicate any significant difference according to gender.

3. Whether online gaming addiction dimensions indicate any difference according to average playing hours.

4. Whether online gaming addiction dimensions indicate any difference according to gaming platforms.

5. Whether online gaming addiction dimensions correlate with gaming platforms.

6. Whether online gaming addiction dimensions correlate with average playing hours.

Based on the recommendation by Faraci et al. (2013), who searched for Internet addiction via the IAT to make a more comprehensive research with a cross-cultural perspective, we made a research on online gaming addiction among Generation Z members focusing on adolescents. The data were gathered from 126 (61.1\%, 77 males and 38.9\%, 49 females) Turkish students in Istanbul Erkek High School, Istanbul, Turkey (implementing a curriculum in European standards) and 73 (47.9\%, 35 males and $52.1 \%$, 38 females) Romanian students in National College Ion Luca Caragiale, Moreni, Romania. The sample was determined for easy accessibility and assistance in data collection according to easily accessible or convenient sample method. Easily available or convenient sampling relies entirely on items that are available, fast, and easy to access (Patton, 2005).

Participants replied questions voluntarily but under the surveillance of a teacher in case of need. Grades ranged from prep class to 11 th $(46.8 \%$, 59 9th graders, $24.6 \%$, 31 prep class students, $17.5 \%$, 22 10th graders and 11.1\%, 14 11th graders) in Turkish school while in Romanian school grades ranged from 9th to 11 th $(38.4 \%, 28$ th graders, $28.8 \%, 2111$ th graders and $27.4 \%, 2010$ th graders). A total of 
199 gamers (aged 13-19; $M=3.10(62.8 \%, 57$ students at the age of 15$), S D=1.30 ; 56.3 \%, 112$ males and $43.7 \%, 87$ females) replied the questionnaire giving not any missing values.

The IAT test questions were presented in English to the students from both cultures delivering via an online survey platform in February 2019. The questionnaire was sent to a teacher in Istanbul Erkek Highschool, Istanbul, Turkey, and a teacher in National College "Ion Luca Caragiale", Moreni, Romania. Both teachers informed students about the online questionnaire about online gaming addiction based on voluntariness.

The Internet Addiction Test (IAT), the first validating instrument to assess Internet addiction (Young, 1998), was used to measure online gaming addiction. It depends on the basis of the DSM_IV criteria (Guze, 1995) (Diagnostic and Statistical Manual of Mental Disorders, 4th Edition) for pathological gambling (Faraci, Craparo, Messina, \& Severino, 2013). The test employed five-point Likert scale (neverrarely-sometimes-often-always) with 20 items.

The questions about game kinds, average playing hours, meaning of games, education level of mother and father, game platforms and monthly income were used depending on Cavuş et al.'s study Computer Games and Addiction: A Field Study on University Students (2016).

Based on participants' replies, frequency analysis was conducted to determine descriptive statistics, demographic characteristics of the participants and detailed findings about their digital game behavior. Next, exploratory factor analysis (EFA) was practised to detect the dimensional structure categorizing items belonging to specific factors. The data resulting from the EFA were subjected to confirmatory factor analysis to confirm whether the items were categorized under the true factor subjected to the EFA. The means obtained from the EFA were subjected to independent samples $t$-test to present their impact on gender and one-way ANOVA test in order to present their impact on game platforms and average playing hours that online gamers tend to. Finally, correlation analysis was conducted to depict the strength level and direction of the correlation between dimensions (factors).

\section{RESULTS}

Frequency Analysis: Average playing hours, most preferable game platforms and game kinds by students, the meaning of games for them, monthly income of their parents and education level of 
their parents in both cultures were found via frequency analysis. Besides, we gave participants demographic characteristics about gender, age, grade in previous parts of the study through frequency analysis.

Average playing hours ranged between 1 and 3 hours, 3.5 and 7 hours, 7.5 and 10 hours, less than 1 hour, more than 15 hours. Participants from Turkey stated they spent 3.5- and 7-hours hours playing online games per day $(28.6 \%, 36 / 126, M=2.71, S D=1.60)$ and later 1 and 3 hours $(27.8 \%$, 35/126). Opposedly, Romanian participants stated playing hours between 1 and 3 hours per day $(45.2 \%$, $33 / 73, M=2.41, S D=1.73)$ and the range of 3.5 to 7 hours follows it $(20.5 \%, 15)$.

Asking students which platforms, they prefer among their smartphone, computer, game console or all these platforms, in both Turkish and Romanian samples the most preferable platform was smartphone (Turkish $=38,9 \%, 49 / 126$ and Romanian $=56,2 \%, 41 / 73$ ). The second most preferable one was all of them $(31,7 \%, 40 / 126)$ in Turkish sample while it was computer $(21,9 \%, 16 / 73)$ in Romanian sample.

Game kinds which participants prefer to play are listed in the questionnaire as tactics, action, puzzle, adventure, sports, roleplay, simulation. All the 126 Turkish students stated that they play tactics games, 100 of them play action games and 69 of them play puzzle games. On the other hand, among 73 Romanian students 33 stated they play action games, 31 of them preferred adventure games and 20 of them played tactics games.

Another important question was what playing digital games meant to them. The answers varied in spending time, entertainment, socialization, pleasure, adrenalin, stress, moving from the real world, prestige, feeling precious, shame, anxiety, belonging to a community, reputation, and dependence. For all 126 Turkish participants the meaning of playing digital games was spending time, for 109 students it meant entertainment and 64 of them stated it meant socialization. Romanian students followed the same way with Turkish students. All the 73 Romanian participants said that it meant spending time, 51 of them played for entertainment and 30 Romanian participants stated they played digital games to socialize. Not any students either in Turkey or Romania stated the meaning of playing digital games for them was anxiety, belonging to a community, reputation, or dependence. 
Asking to Turkish students about monthly income of their family, they replied the question according to TL (Turkish Lira) ranges: 500-2000 TL, 2100-5000 TL, 5100-8000 TL, 8100-10000 TL, more than 10000 TL. Turkish participants stated it was between 5100-8000 TL ( $M=3.66, S D=1.01)$. Romanian participants gave their replies according to ranges: 500-2000 €, 2100-5000 €, 5100-8000€, 8100-10000 €, more than $10000 €$. Their average monthly income was between $500-2000 €(M=1.56$, $S D=1.20)$

Education level of parents was demanded from participants to determine whether there was a correlation between dimensions of online gaming addiction. Education levels were aligned in primary school, middle school, high school, university, master's degree and doctorate. Education level of Turkish participants' mothers was commonly university $(57.1 \%, 72 / 126)$, master's degree $(19.8 \%, 25 / 126)$ and high school (13.5\%, 17/126). The common education levels of Romanian participants' mothers were high school $(63.0 \%, 46 / 73)$, university $(17.8 \%, 13 / 73)$ and master's degree $(8.2 \%, 6 / 73)$. As for education levels of fathers in both cultures, Turkish fathers' education level focused on university $(53.2 \%, 67 / 126)$, master's degree $(22.2 \%, 28)$ and high school $(12.2 \%, 16)$. Romanian participants' fathers were seen to have graduated from high school $(58.9 \%, 43 / 73)$, university $(19.2 \%, 14 / 73)$ and master's degree $(11.0 \%$, 8/73).

Independent Samples T-test: Independent samples T-test indicated if there was a significant difference between genders in terms of online gaming addiction dimensions, Emotional and Cognitive Preoccupation with Online Gaming and Loss of Control and Interference with Daily Life. According to the replies obtained from Turkish sample, both Emotional and Cognitive Preoccupation with Online Gaming ( $\mathrm{t}=-$ 3.15; $\mathrm{p}<.05)$ and Loss of Control and Interference with Daily Life ( $\mathrm{t}=-3.36 ; \mathrm{p}<.01)$ dimensions have significant difference in terms of gender. Analyzing descriptive statistics, males ( $M=1.83, S D=.64)$ were seen to be affected more by Emotional and Cognitive Preoccupation with Online Gaming than females ( $\mathrm{M}=$ $1.48, \mathrm{SD}=.54)$. Similarly, males $(\mathrm{M}=2.22, \mathrm{SD}=.68)$ were more subjected to Loss of Control and Interference with Daily Life than females $(\mathrm{M}=1.77, \mathrm{SD}=.68)$. Romanian sample indicated in neither Emotional and Cognitive Preoccupation with Online Gaming nor Loss of Control and Interference with Daily Life significant difference were available in terms of gender. 
One-way ANOVA test: ANOVA test provided findings about if the was any significant difference between digital gaming platforms or average playing hours in terms of terms of online gaming addiction dimensions, Emotional and Cognitive Preoccupation with Online Gaming and Loss of Control and Interference with Daily Life.

The data from Turkish sample indicated both Emotional and Cognitive Preoccupation with Online Gaming ( $F=5.42 ; \mathrm{p}<.01)$ and Loss of Control and Interference with Daily Life $(F=4.64 ; \mathrm{p}<.01)$ dimensions have significant difference in terms of digital gaming platforms. Analyzing descriptive statistics, smartphone $(M=1.46, S D=.50)$ was more effective in Emotional and Cognitive Preoccupation with Online Gaming than the other platforms: all of them $(M=1.96, S D=.72)$, computer $(M=1.76, S D=.58)$ and game console $(M=1.48, S D=.35)$. Similarly, mostly smartphone $(M=1.83, S D=.70)$ was subjected to Loss of Control and Interference with Daily Life. The other platforms were found to be less effective in this factor: all of them $(M=2.36, S D=.75)$, computer $(M=2.04, S D=.58)$ and game console $(M=1.79, S D=.41)$. In Romanian sample no significant findings could be reached in either Emotional and Cognitive Preoccupation with Online Gaming or Loss of Control and Interference with Daily Life in terms of digital gaming platforms.

Besides, average playing hours were tested by ANOVA. In Turkish sample both Emotional and Cognitive Preoccupation with Online Gaming $(\mathrm{F}=10.41 ; \mathrm{p}<.01)$ and Loss of Control and Interference with Daily Life $(\mathrm{F}=10.31 ; \mathrm{p}<.01)$ dimensions indicated significant difference in terms of average playing hours. Descriptive statistics presented the most leading range was between 3.5 and 7 hours $(M=1.74, S D=.55)$ in Emotional and Cognitive Preoccupation with Online Gaming. Findings about the other platforms were aligned in this way: 1 and 3 hours $(M=1.45, S D=.42)$, less than hour $(M=1.39, S D=.50), 7.5$ and 10 hours $(M=1.88, S D=.61)$, more than 15 hours $(M=2.87, S D=.71)$ and 10.5 and 15 hours $(M=1.96, S D=.64)$. Loss of Control and Interference with Daily Life factor, the most effective playing hour range was between 3.5 and 7 hours $(M=2.05, S D=$.$) , then; 1$ and 3 hours $(M=1.85, S D=.71)$, less than hour $(M=1.57, S D=$ $.60), 7.5$ and 10 hours $(M=2.33, S D=.59)$, more than 15 hours $(M=3.14, S D=.62)$ and 10.5 and 15 hours $(\mathrm{M}=2.80, \mathrm{SD}=.71)$. Any significant difference could not be found comparing all average playing hour ranges in Romanian sample. 
Correlation Analysis: In the study, two IAT factors Emotional and Cognitive Preoccupation with Online Gaming and Loss of Control and Interference with Daily Life, significantly correlated (Pearson's r) both in Turkish ( $r=.62, \mathrm{p}<.01$, two-tailed) and Romanian sample ( $r=.71, \mathrm{p}<.01$, two-tailed).

In Turkish sample factor 1, Emotional and Cognitive Preoccupation with Online Gaming, was found to be positively correlated with digital gaming platforms ( $r=.30, \mathrm{p}<.01$, two-tailed) and average playing hours ( $r=.22, \mathrm{p}<.05$, two-tailed) but no correlation with education level of mother or father or monthly income. Factor 2, Loss of Control and Interference with Daily Life was similarly found to be positively correlated with digital gaming platforms ( $r=.29, \mathrm{p}<.01$, two-tailed) while it does not have any correlation with average playing hours, education level of mother or father or monthly income. Opposite to Turkish sample, in Romanian sample neither factor was found to be correlated with digital gaming platforms, average playing hours, education of mother or father or monthly income

\section{Principal findings}

Exploratory Factor Analyses: As Turkish sample indicates the KMO's Test of Sampling Adequacy was .84 and Bartlett's Test of Sphericity $(\chi 2190=1060.2)$ was significant $(P<.001)$. So, the Internet Addiction Test (IAT) items could be said to be appropriate for a factor analysis. On the other hand, according to the data from Romanian sample, the KMO's Test of Sampling Adequacy was .72 and Bartlett's Test of Sphericity $(\chi 2190=628.5)$ was significant $(P<.001)$, indicating that the IAT items were also appropriate for a factor analysis although it resulted in weaker figures. Regarding anti-image matrices, anti-image correlation results were found to be over 50 in both samples.

Revising many studies throughout the present study, Cavus et al.' s (2016) adapting the IAT into digital gaming and Faraci et.al's (2013) the two-factor solution of the IAT have lighted our way. Faraci et al. (2013), named their first factor "Emotional and Cognitive Preoccupation with the Internet" and second factor "Loss of Control and Interference with Daily Life", which they stated they utilised the original wording proposed by Barke, Nyenhuis, and Kröner-Herwig (Faraci, Craparo, Messina, \& Severino, 2013). We also took permission to adapt their factor wording in our study. Stemming from Faraci et al.'s (2013) two-factor solution, examination of Turkish sample revealed 19 items were appropriate. Item 19 ("Do you try to hide how long you spent time with the game?") did not have any loadings. On the other hand, Romanian sample indicated 16 items were appropriate. Item 13 ("Do you forget to spend time with the 
games about the disturbing thoughts about your life?"), item 7 ("Does a life without games frighten you, boring, empty and unappealing?") and item 8 ("Can you react to someone who interferes with the game by talking?") bear double loadings; and item 1 does not bear any loadings. According to the two-factor solution, explaining (Turkish $=44.16 \%$ of total variance, Romanian $=41.75 \%$ of total variance), Factor 1 (Emotional and Cognitive Preoccupation with Online Gaming) involved 10-item-loading in both samples while Factor 2 (Loss of Control and Interference with Daily Life) represented 9 items in Turkish sample but 6 items in Romanian sample. As the EFA results reported, factors intercorrelation was 62 in Turkey and .71 in Romania. For Factor 1, the eigenvalue was Turkish= 6.94 and Romanian $=6.47$ and the variance explained was Turkish $=22.72$ and Romanian $=22.02$. For Factor 2 , the eigenvalue was Turkish $=$ 1.88 and Romanian= 1.87 and the variance explained was Turkish $=21.44$ and Romanian $=19.73$. Finally, the reliability for the two-factor solution model of the IAT according to both Turkish and Romanian samples was satisfactory. The Turkish sample reliability coefficient was Cronbach alpha $=.897$ (Factor 1 Cronbach alpha $=.828$ Factor 2 Cronbach alpha $=.820$ ). The Romanian sample reliability coefficient was more satisfactory with Cronbach alpha $=.896$ (Factor 1 Cronbach alpha $=.819$ Factor 2 Cronbach alpha=.773).

Table 1 depicts items' loadings, trends participants tend to, eigenvalues, variances explained and reliability results according to Turkish Sample. Factors intercorrelation according to the results of the EFA was.62. The reliability of the IAT was found to be high (Cronbach's $\alpha=.897$ ) The results for both factors were also found to be high (Factor 1 Cronbach's $\alpha=, 828$ and Factor 2 Cronbach alpha=,820). In terms of the trends stemming from the replies by the respondents, the leading factor, Factor 1 , is Emotional and Cognitive Preoccupation with Online Gaming, of which the eigenvalue was 6,94, variance explained was 22,72 and reliability coefficient was Cronbach's $\alpha=.828$. The most important items of the factor were ranged "When you're spending time with the game, do you have to say, "I'm going to play a little bit more?" with 2,58 means, "Do you play longer than you intended?" with 2,46 means and "Have you tried to reduce the time spent with the game?" with 2,33 means. The second factor is Loss of Control and Interference with Daily Life. Its eigenvalue was 1,88, variance explained was 21,44 and reliability coefficient was Cronbach's $\alpha=.820$. The leading items were respectively stated as "Do you spend time with the games to forget about the disturbing thoughts about your life?" with 2,24 means, "Do you build 
new friendships through the game?" with 1,99 means and "Does a life without games frighten you about being boring, empty and unappealing?" with 1,86 means.

Table 1 Factor Loadings And Mean Of The IAT Items For The Two-Factor Solution According To Turkish Sample

\begin{tabular}{|c|c|c|c|}
\hline Items & $\overline{\mathrm{X}}$ & 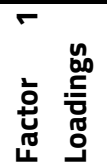 & $\begin{array}{ll}N \\
\\
\end{array}$ \\
\hline
\end{tabular}

Factor 1: Emotional and Cognitive Preoccupation with Digital Game

15. Do you build new friendships through the game?

14. When you are spending time with the game, do you have to say, "I am going to play 2,52, 706 a little bit more?"

12. Do you play longer than you intended?

18. Would you prefer to spend time with the game and go out with someone?

11. Do you find yourself thinking about playing games again?

16. Have you tried to reduce the time spent with the game?

4. Do you think of playing often, even though you are busy?

17. Would you prefer the excitement of playing games to your friend's sincerity?

6. Would you be sleepless because of the time you spent playing games?

3. Are you neglecting your work because you spend too much time in the game?

\section{Factor 2: Loss of Control and Interference with Daily Life}

10. Do you get pensive when you are not playing games or dreaming of playing games? 1,79

19. Do you try to hide how long you spent time with the game?

20. When someone asks about games, do you have a defensive attitude or an attitude 2,01 that disguises you? 
5. Do other people in your life feel uneasy about your time with the game?

9. Do you feel depressed, pessimistic, or angry when you are not playing?

2. Does your school performance or course efficiency suffer from game play?
1,83

$-630$

1,61

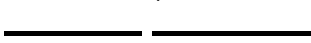

EIGENVALUE

VARIANVE EXPLAINED

Cronbach's Alpha
1,93
6,48

1,87

$41,75 \quad 22,02$

,896 $\quad$ 819 , 773

Table 2 depicts items' loadings, trends participants tend to, eigenvalues, variances explained and reliability results according to Romanian Sample. Factors intercorrelation according to the results of the EFA was.71. The reliability of the IAT was high (Cronbach's $\alpha=.896)$. The results for both factors were found to be high (Factor 1 Cronbach's $\alpha=, 819$ and Factor 2 Cronbach alpha $=, 773$ ). In terms of the trends stemming from the replies by the respondents, the leading factor, Factor 1, is Emotional and Cognitive Preoccupation with Online Gaming, of which the eigenvalue was 6,48, variance explained was 22,02 and reliability coefficient was Cronbach's $\alpha=.819$. The most important items of the factor were ranged "When you are spending time with the game, do you have to say, "I am going to play a little bit more?" with 2,52 means, "Do you build new friendships through the game" with 2,49 means and "Have you tried to reduce the time spent with the game?" with 2,42 means. The second factor is Loss of Control and Interference with Daily Life. Its eigenvalue was 1,87, variance explained was 19,73 and reliability coefficient was Cronbach's $\alpha=.773$. The leading items were respectively stated as "When someone asks about games, do you have a defensive attitude or an attitude that disguises you?" with 2,01 means, "Do you try to hide how long you spent time with the game?" with 1,97 means and "Does your school performance or course efficiency suffer from game play?" with 1,93 means. 
Table 2 Factor Loadings And Mean Of The IAT Items For The Two-Factor Solution According To Romanian Sample

\begin{tabular}{|c|c|c|c|}
\hline & $\bar{Y}$ & & $\mathbf{N}$ \\
\hline Items & & 竞 & 总 \\
\hline
\end{tabular}

Factor 1: Emotional and Cognitive Preoccupation with Digital Game

15. Do you build new friendships through the game?

$2,49 \quad 757$

14. When you are spending time with the game, do you have to say, "I am going to play 2,52 , 706 a little bit more?"

12. Do you play longer than you intended?

18. Would you prefer to spend time with the game and go out with someone?

11. Do you find yourself thinking about playing games again?

16. Have you tried to reduce the time spent with the game?

4. Do you think of playing often, even though you are busy?

17. Would you prefer the excitement of playing games to your friend's sincerity?

6. Would you be sleepless because of the time you spent playing games?

3. Are you neglecting your work because you spend too much time in the game?

\section{Factor 2: Loss of Control and Interference with Daily Life}

10. Do you get pensive when you are not playing games or dreaming of playing games? 1,79

20. When someone asks about games, do you have a defensive attitude or an attitude 2,01 that disguises you? 
9. Do you feel depressed, pessimistic, or angry when you are not playing?

2. Does your school performance or course efficiency suffer from game play?
1,61

551

1,93

, 522

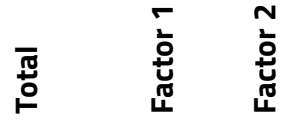

6,48

1,87

EIGENVALUE

41,75

22,02

VARIANVE EXPLAINED

,896

819

87

\section{Confirmatory Factor Analysis}

Model 1: The original model was analyzed according to the two-factor-solution with 19 items, Emotional and Cognitive Preoccupation with Online Gaming (was represented by 3, 12, 2, 1, 14, 4, 5, 16, 6, 8) and Loss of Control and Interference with Daily Life (was represented by 18, 7, 11, 9, 10, 17, 15, 20, 13) based on the EFA of Turkish Sample while it was conducted with 16 items, Emotional and Cognitive Preoccupation with Online Gaming (was represented by 15, 14, 12, 18, 11, 16, 4, 17, 6, 3) and Loss of Control and Interference with Daily Life ( was represented by 10, 19, 20, 5, 9, 2) based on the EFA of Romanian Sample. With these figures, Model 1 indicated poor fit indexes with Turkish sample $(n=126)$ and Romanian sample $(\mathrm{n}=73)$. According to Turkish sample goodness-of-fit indexes were poor $(P<.001$, $\chi 2 / \mathrm{df}=2.58, \mathrm{CFI}=.80, \mathrm{RMSEA}=.08, \mathrm{GFI}=.83$ and $\mathrm{RMR}=.08$ ). On the other hand, Romanian Sample reflected poor goodness-of-fit indexes, as well $(P<.001, \chi 2 / \mathrm{df}=3.43, \mathrm{CF} \mid=.76, \mathrm{RMSEA}=.11, \mathrm{GF}=.85$ and $\mathrm{RMR}=.08$ ).

Model 2: Model 2 was analyzed removing item 19 of Emotional and Cognitive Preoccupation with Online Gaming with loading .38 in Turkish sample and loading .37 in Romanian sample. Model 2 indicated poor fit indexes with both samples. According to Turkish sample goodness-of-fit indexes were poor $(P<.001, \chi 2 / \mathrm{df}=2.75, \mathrm{CFI}=.80, \mathrm{RMSEA}=.09, \mathrm{GFI}=.84$ and $\mathrm{RMR}=.08)$. On the other hand, Romanian Sample reflected poor goodness-of-fit indexes, as well $(P<.001, \chi 2 / \mathrm{df}=3.75, \mathrm{CF}=.76, \mathrm{RMSEA}=.11, \mathrm{GFI}=.81$ and $\mathrm{RMR}=.08)$. 
Model 3: Model 3 was conducted correlating item 14 to item 12 of Emotional and Cognitive Preoccupation with Online Gaming in Turkish Sample and item 12 to item 14 of the same factor in Romanian sample. Model 3 could not still signify some of the fit indexes reasonably in both samples even though they reflected better indices. According to Turkish sample goodness-of-fit indexes were not still significant or acceptable $(P<.001, \chi 2 / \mathrm{df}=2.43, \mathrm{CFI}=.84, \mathrm{RMSEA}=.08, \mathrm{GFI}=.84$ and $\mathrm{RMR}=.08)$. On the other hand, Romanian Sample did not reflect significant or acceptable goodness-of-fit indexes, as well $(P<.001, \chi 2 / \mathrm{df}=3.25, \mathrm{CFI}=.80, \mathrm{RMSEA}=.11, \mathrm{GFI}=.81$ and $\mathrm{RMR}=.08)$.

Model 4: The confirmatory factor analysis (CFA) conducted on Turkish sample $(n=126)$ reflected the acceptable goodness-of-fit indexes $(\chi 2$ 132=303.12; $P<.001, \chi 2 / \mathrm{df}=2.29, \mathrm{CFI}=.85$, RMSEA=.08, $\mathrm{GFI}=.86$ and $\mathrm{RMR}=.07)$. The CFA for Romanian sample $(\mathrm{n}=73)$ comparatively resulted in the acceptable goodness-of-fit indexes $(\chi 2$ 87=235.64; $P<.001, \chi 2 / \mathrm{df}=2.70, \mathrm{CFI}=.85, \mathrm{RMSEA}=.09, \mathrm{GFI}=.85$ and $\mathrm{RMR}=.07)$. Modification indexes fit significantly and acceptable correlating Factor 1, Emotional and Cognitive Preoccupation with Online Gaming, and correlating high (Turkish $=.76$ and Romanian $=.86$ ) with the second factor Loss of Control and Interference with Daily Life. Both Turkish and Romanian samples fit significantly in terms of chi-square fit indexes (Tabachknick \& Fidell, 2001); (Kline, 2005); (Simon, et al., 2010)). Comparative fit index was acceptable in both samples (Dehon, Weems, Stickle, Costa, \& Berman, 2005). Root mean square error of approximation indicated significant fit according to Turkish sample but poor fit in Romanian sample (Tabachknick \& Fidell, 2001); (Simon, et al., 2010). Goodness of fit index indicated acceptable figures in both samples ( (Fox, 2002) (Simon, et al., 2010)). Root Mean Squared Residual signifies reasonable with the same figure in both samples (Schermelleh-Engel, Moosbrugger, \& Müller, 2003). Table 3 depicts the results of the CFA goodness-of-fit indexes for both samples.

Table 3 Fit Indices For Turkish And Romanian Samples

\begin{tabular}{lllllllll}
\hline Sample & $\chi 2$ & Df & $\chi 2 / d f$ & $P$ Value & CFI & RMSEA & GFI & SRMR \\
\hline Turkish & 303.12 & 132 & 2.29 & $<.001$ & .85 & .08 & .86 & .07 \\
Romanian & 235.64 & 87 & 2.70 & $<.001$ & .85 & .09 & .85 & .07 \\
\hline
\end{tabular}

Correlation between factors was 0.76 for Turkish sample while it was 0.86 for Romanian sample. According to the results of the CFA, the latent factors were found to be highly correlated to each other. 
Table 4 depicts standardised parameter estimates of the CFA in Turkish sample while Table 5 reflects standardised parameter estimates of the CFA in Romanian sample.

Table 4 CFA Loadings And Correlation Between Latent Factors of Turkish Sample

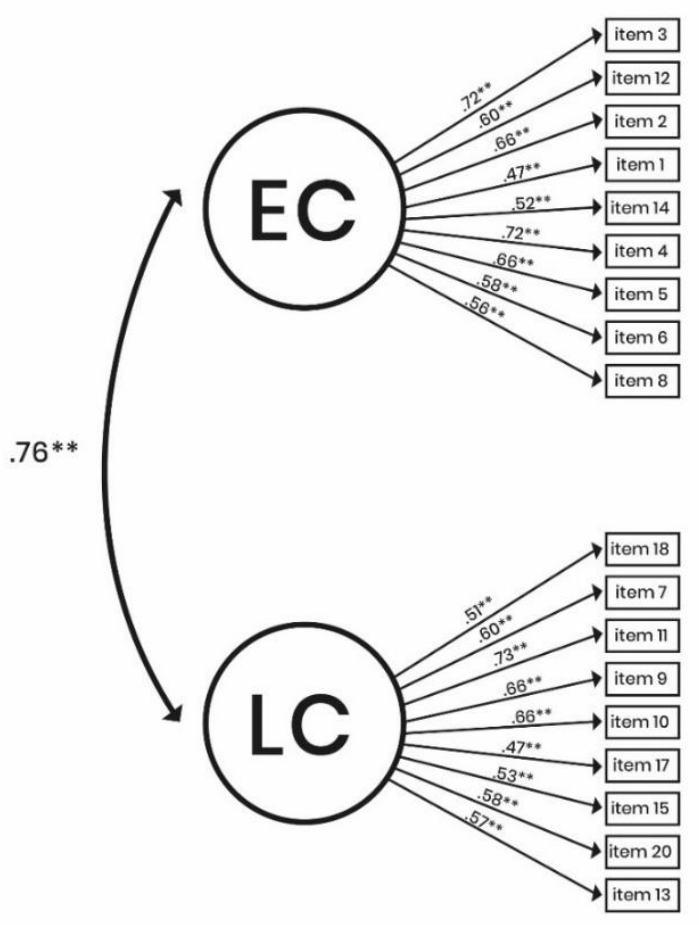

Table 5 CFA Loadings And Correlation Between Latent Factors of Romanian Sample

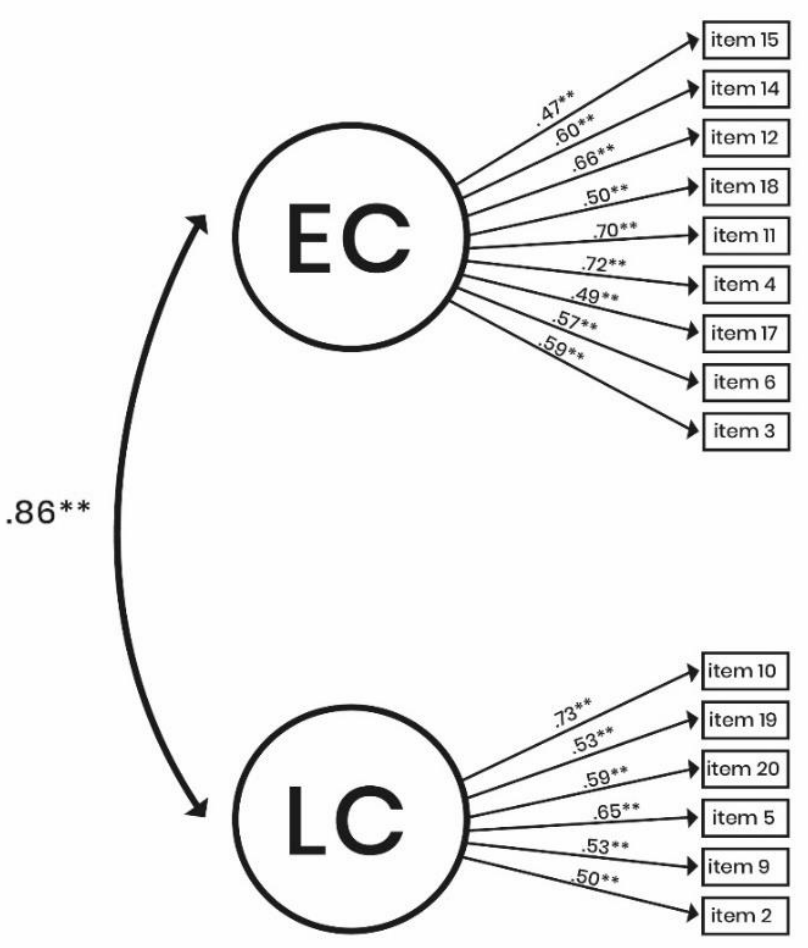




\section{DISCUSSION}

Practising 20-item-test firstly in exploratory factor analysis, 19 items were extracted in Turkish sample while 16 items were extracted in Romanian sample. In Turkish sample, two-factor-dimension (Factor 1, emotional and cognitive preoccupation with online gaming involving 10 items with $22.72 \%$ variance explained and Factor 2, loss of control and interference with daily life loaded with 9 items with $21.44 \%$ variance explained) explained $44.19 \%$ of total variance. Factors intercorrelation was .62 and reliability coefficient was Cronbach alpha $=.897$ (Factor 1 Cronbach alpha $=.828$ Factor 2 Cronbach alpha=.820). On the other hand, in Romanian sample, the same structure of online gaming addiction explained $41.75 \%$ of total variance (Factor 1, emotional and cognitive preoccupation with online gaming involving 10 items with $22.02 \%$ variance explained and Factor 2, loss of control and interference with daily life loaded with 6 items with $19.73 \%$ variance explained). The intercorrelation of factors were .71 and reliability coefficient was Cronbach alpha $=.896$ (Factor 1 Cronbach alpha $=.819$ Factor 2 Cronbach alpha=.773). With slightly different figures, both cultures presented satisfactory results indicating the consistency of the original two-dimension structure of Internet addiction with the two-factor-solution of online gaming addiction, which indicated positive intercorrelation.

The EFA (exploratory factor analysis) was verified by the CFA (confirmatory factor analysis) with general manner of acceptable estimates because of four-model- modification indices. Modification indexes fit significantly in both samples with strong intercorrelation of two latent factors (Turkish $=.76$ and Romanian= .86), even slightly stronger in Romanian sample. In both samples, goodness-of-fit indexes were found to be acceptable, which included significant chi-square fit indexes. Comparative fit index (CFI) and goodness of fit index (GFI) were found to be acceptable in both samples. Root Mean Squared Residual (RMR) equally signified reasonable in both samples. Root mean square error of approximation (RMSA) fit significantly to Turkish sample but indicated poor fit in Romanian sample.

Significant difference between genders was found in Turkish sample while in Romanian sample both female and male participants were similarly affected by both factors of online gaming addiction. In Turkey, male participants were found to be more affected by both emotional and cognitive preoccupation with online gaming and loss of control and interference with daily life than females. 
Analyzing average playing hour ranges, we found out both emotional and cognitive preoccupation with online gaming and loss of control and interference with daily life indicated significant difference with average playing hours in Turkish sample. The most leading playing hour range was 3.5 and 7 . Contrary to Turkish sample, no significant difference was found among average playing hour ranges according to Romanian sample. And they play shorter hours- 1 and 3 hours. Another remarkable result about average playing hours was its positive correlation with emotional and cognitive preoccupation with online gaming in Turkish sample but not in Romanian sample.

Findings about gaming platforms indicated the same pattern with the duration of playing. Both factors signified difference again in Turkish sample but not in Romanian sample. However, in both cultures' participants stated they mostly used smartphone for online gaming. Both emotional and cognitive preoccupation with online gaming and loss of control and interference with daily life dimensions positively correlated with online gaming platforms in Turkish sample but not in Romanian sample. The most common game kind among all Turkish participants was tactics games while it was action games among Romanian participants, which did not have to do with any effect on online gaming addiction. All participants from both Turkey and Romania stated playing online games meant spending time. A remarkable result was that playing online games meant anxiety, belonging to a community, reputation, or dependence to participants from neither sample.

In conclusion, two-factor solution of Internet addiction- emotional and cognitive preoccupation with online gaming and loss of control and interference with daily life - fit well into online gaming addiction in the comparative version of the IAT with Turkish and Romanian samples. In the present cross-cultural study, comparing two participants Turkish sample indicated more remarkable results in terms of significant difference of gender according to factors, the correlation between online gaming addiction factors and gaming platforms or duration of gaming. Finally, some descriptive statistics about game kinds, meaning of playing online games, duration of gaming and gaming platforms in samples of two different cultures showed no correlation with online gaming addiction. Barke (2014) suggested this type of studies could be used in the settings of cognitive behavioral therapy. Deriving from conclusions in the present study and suggestions by previous researchers, cognitive behavioral therapy could be seen an alternative solution for emotional and cognitive preoccupation with online gaming and loss of control and interference with daily life in online gaming addiction. Looking at outstanding results in the relationship 
between online gaming addiction and gaming duration and gaming platforms especially in Turkish sample, a limitation on duration and gaming platform could be suggested. However, it would be helpful to keep the impossibility of depriving Generation Z'ers of online gaming in mind. So as results of the present study and previous research (Dye, Green, \& Bavelier, 2009); (McKinley, McIntire, \& Funke, 2011) indicated, the most common game kinds all participants play, action games or tactics game, could be utilised to develop their decision-making skill and capability of doing professional work. Regarding both samples' view about meaning of playing online games, spending time, entertainment, and socializationthe most common meanings - could be turned into advantages during recovery of online gaming addiction.

\section{LIMITATIONS AND SUGGESTIONS FOR FUTURE RESEARCH}

Sample size in both countries was limited because of the month when the survey was conducted - February 2019. Not all students were present at school on those days because of closing semester holiday and the voluntary. So, the rest of the students were able to be reached thanks to both teachers' effort in Romania and Turkey. More cross-cultural research comparing more than two cultures needs to be done with larger sample size.

\section{GENIŞLETILMiş ÖZET}

Farklı nesiller, çevrelerinden geniş ölçüde etkilenen farklı davranış özelliklerine sahiptir. Dolayısıyla, Z Kuşağının davranışsal karakteristik gelişimi de önemli ölçüde farklı ve güncel bağlamlar ve çevrelerden etkilenmektedir. Son derece sofistike bir teknolojik ortamla birlikte büyümekte olan Z kuşağı seleflerine kıyasla medyayı ve tüm teknolojik ürünleri muhtemelen çok daha ustalıkla kullanmaktadır.

Online oyun bağımlılığı, 1 ) oyun üzerinde bozulmuş kontrol (örneğin, başlangıç, sıklık, yoğunluk, süre, sonlandırma, bağlam); 2) oyun oynamanın diğer yaşam ilgi alanlarından ve günlük aktivitelerden öncelikli olduğu ölçüde oyun oynamaya verilen önceliği artırmak; ve 3) olumsuz sonuçların ortaya çıkmasına rağmen oyunun devam etmesi veya tırmanması şeklinde belirtilerle kendini gösteren; çevrimiçi (yani İnternet üzerinden) veya çevrimdışı olabilen, sürekli veya tekrarlayan oyun davranışları ('dijital oyun' veya 'video oyunları') ile karakterize edilmektedir. Davranış örüntüsü kişisel, ailevi, sosyal, eğitimsel, mesleki veya diğer önemli işleyiş alanlarında önemli bozulmalara neden olacak kadar ciddi boyuttadır. Oyun davranışının örüntüsü sürekli veya dönemsel ve tekrarlayan şekillerde olabilmektedir. 
Oyun davranışı ve diğer özellikler, bir tanı konulabilmesi için normalde en az 12 aylık bir süre boyunca belirgin olmalıdır, ancak tüm teşhis gereksinimleri karşılanırsa ve semptomlar şiddetliyse gerekli süre kısa tutulabilir. Bağımlıık türü oyun davranışları ve özellikleri, oyun bağımlılığına neden olabilir. Birçok Z Kuşağı üyesi, duygusal ve bilişsel olarak çevrimiçi oyunla meşgul olabilir; hatta kontrollerini kaybedebilir ve bu durum günlük yaşamlarına müdahale edebilir.

IAT testi soruları, Şubat 2019'da çevrimiçi bir anket platformu aracıllğıyla her iki kültürden öğrencilere İngilizce olarak sunuldu. İnternet bağımlılığını değerlendiren ilk doğrulama aracı olan İnternet Bağımlılı̆ı Testi (IAT), çevrimiçi oyun bağımlılığını ölçebilmektedir. Testte, 20 maddeli beşli Likert ölçeği (asla-nadiren-bazen-sık sık-her zaman) kullanılmıştır.

Oyun türleri, ortalama oyun saatleri, oyunların anlamı, anne ve babanın eğitim düzeyi, oyun platformları ve aylık gelir ile ilgili sorular Çavuş ve arkadaşlarının Bilgisayar Oyunları ve Bağımılık: Üniversite Öğrencileri Üzerine Bir Saha Çalışması çalışmasına bağlı olarak kullanıımıştır.

Katılımcıların cevaplarına göre, katılımcıların tanımlayıcı istatistikleri, demografik özellikleri ve dijital oyun davranışları hakkında detaylı bulguları belirlemek için frekans analizi yapılmıştır. Daha sonra, belirli faktörlere ait maddeleri kategorize eden boyutsal yapıyı tespit etmek için açımlayııı faktör analizi (EFA) uygulanmıştır. EFA'dan elde edilen veriler, maddelerin EFA'ya tabi gerçek faktör altında kategorize edilip edilmediğini doğrulamak için doğrulayıc faktör analizine tabi tutulmuştur. EFA'dan elde edilen veriler, oyun platformlarının katılımcılar üzerindeki etkilerini ve çevrimiçi oyuncuların ortalama oyun saati eğilimlerini ortaya koymak için ve cinsiyet üzerindeki etkisini göstermek için bağımsız örneklem t-testine ve tek yönlü ANOVA testine tabi tutulmuştur. Son olarak, boyutlar (faktörler) arasındaki korelasyonun güç seviyesini ve yönünü göstermek için korelasyon analizi yapıımıştır.

Türk örneklemi, KMO'nun Örnekleme Yeterlilik Testi'nin .84 olduğunu ve Bartlett Küresellik Testi'nin ( $x 2190=1060.2)$ anlamlı olduğunu $(P<.001)$ göstermiştir. Diğer yandan; Romanya örnekleminden alınan verilere göre, KMO'nun Örnekleme Yeterlilik Testi .72 ve Bartlett Küresellik Testi $(\chi 2190=628.5)$ anlamlıydı $(P<.001)$, bu da ÖÇT maddelerinin faktör analizi için uygun olduğunu göstermektedir. Faraci ve arkadaşlarının iki faktörlü çözümünden yola çıkarak, Türk örnekleminin incelenmesi 19 maddenin uygun olduğunu ortaya çıkarmıştır. Madde 19'da ("Oyunla ne kadar zaman geçirdiğinizi gizlemeye çalışır mıınız?") herhangi bir faktör yükü sergilememeiştir. Öte yandan, Romanya 
örneği 16 maddenin de uygun olduğunu göstermiştir. Madde 13 ("Hayatınızla ilgili rahatsız edici düşünceleri oyunlarla vakit geçirirken unutuyor musunuz?"), Madde 7 ("Oyunsuz bir hayat sizi korkutuyor mu, sıkıcı, boş ve çekici değil mi?") ve Madde 8 ("Oyuna müdahale eden birine konuşarak tepki verir misin?") çift yük taşımaktadır; 1. madde ise herhangi bir faktör yükü göstermemektedir. İki faktörlü çözüme göre, açıklayan (Türkçe = toplam varyansın\%44,16'sı, Romanya = toplam varyansın\%41,75'i), Faktör 1 (Çevrimiçi Oyunla Duygusal ve Bilişsel Kaygı) her iki örnekte de 10 maddelik yükleme, Faktör 2 (Kontrol Kaybı ve Günlük Hayata Müdahale) Türkiye örnekleminde 9, Romanya örnekleminde 6 madde ile temsil edilmektedir. EFA sonuçlarının bildirdiği gibi, faktörler arası korelasyon Türkiye'de .62 ve Romanya'da.71'dir.

Öne çıkan maddeler sırasıyla "Hayatınızla ilgili rahatsı edici düşünceleri unutmak için oyunlarla vakit geçiriyor musunuz?" 2,24 ile "Oyun aracıllğıyla yeni arkadaşlıklar kuruyor musunuz?" 1,99 ile anlamlıdır ve "Oyunsuz bir hayatın sıkıcı, boş ve çekici olmama konusu sizi korkutuyor mu?" 1,86 ile anlamlıdır.

Faktörün en önemli maddeleri şöyle sıralanmıştır: "Oyunla vakit geçirirken, biraz daha oynayacağım mı? dersiniz" 2,52 ile "Oyun aracılığıyla yeni arkadaşlıklar kurar mısınız" ve 2,49 anlamıyla "Oyunla geçirilen zamanı azaltmaya çalıştınız mı?" 2,42 anlamına gelir. İkinci faktör, Kontrol Kaybı ve Günlük Hayata Müdahaledir. Öz değeri 1,87, açıklanan varyans 19,73 ve güvenilirlik katsayısı Cronbach'ın $\alpha=.773$ 'tü. Başlıca maddeler sırasıyla "Biri oyun sorduğunda, savunmacı bir tavrınız veya sizi gizleyen bir tavrınız var mı?" Şeklinde belirtilmiştir. 2,01 ile "Oyunla ne kadar zaman geçirdiğinizi gizlemeye çalışır mısınız?" 1,97 anlamına gelir ve "Okul performansınız veya kurs verimliliğiniz oyun oynamaktan etkileniyor mu?" 1,93 anlamına gelir.

Faktörler arası korelasyon Türk örnekleminde 0,76 iken Romanya örnekleminde 0,86'dır. DFA sonuçlarına göre, örtük faktörlerin birbiriyle yüksek oranda ilişkili olduğu bulunmuştur.

Her iki örneğin çevrimiçi oyun oynamanın anlamı hakkındaki görüşlerinden orataya çıkan vakit geçirmek, eğlenmek ve sosyalleşmek gibi en yaygın anlamlar; çevrimiçi oyun bağımlılı̆ını iyileştirme sürecinde avantaja dönüştürülebilir. 


\section{REFERENCES}

Barke, A., Nyenhuis, N., \& Kröner-Herwig, B. (2014, July). The German version of the generalized pathological internet use scale 2: A validation study. Cyberpsychology, Behavior, and Social Networking, 17(7), 474-482. doi:https://doi.org/10.1089/cyber.2013.0706

Blinka, L. (2015). Online gaming addiction: The role of avatars and sociability of gamers. Brno, Czechia: Masaryk University Faculty of Social Studies.

Çavuş, S., Ayhan, B., \& Tuncer, M. (2016, Güz). Bilgisayar oyunları ve bağımlııı: Üniversite öğrencileri üzerine bir alan araştırması. Iletişim Kuram ve Araştırma Dergisi(43), 265-289.

Dehon, C., Weems, C. F., Stickle, T. R., Costa, N. M., \& Berman, S. L. (2005). A cross-sectional evaluation of the factorial invariance of anxiety sensitivity in adolescents and young adults. Behaviour Research and Therapy, 43(6), 799-810. doi:https://doi.org/10.1016/j.brat.2004.06.008

Dye, M. W., Green, C. S., \& Bavelier, D. (2009). Increasing speed of processing with action video games. CURRENT DIRECTIONS IN PSYCHOLOGICAL SCIENCE, 18(6), 321-326.

Ekinci, N. E., Ilimdar, Y., Özer, Ö., \& Kara, T. (2017). An investigation of the digital game addiction between. International Journal of Human Sciences, 14(4), 4989-4994. doi:10.14687/jhs.v14i4.4936

Faraci, P., Craparo, G., Messina, R., \& Severino, S. (2013, October). Internet Addiction Test (IAT): Which is the best factorial solution? J Med Internet Res, 15(10). doi:10.2196/jmir.2935

Ferguson, C. J., Coulson, M., \& Barnett, J. (2011, December). A meta-analysis of pathological gaming prevalence and comorbidity with mental health, academic and social problems. Journal of Psychiatric Research, 45(12), 1573-1578. doi:https://doi.org/10.1016/j.jpsychires.2011.09.005

Fox, J. (2002). Structural equation models appendix to an R and S-PLUS companion to applied regression. Retrieved from https://legacy.fordham.edu/economics/vinod/sim-eq-in-R.pdf

Guze, S. B. (1995). Diagnostic and Statistical Manual of Mental Disorders, 4th ed. (DSM-IV). American Journal of Psychiatry, 152(8), 1228-1228. doi:https://doi.org/10.1176/ajp.152.8.1228

Kline, R. B. (2005). Principles and practice of structural equation modeling (Second Edition ed.). New York: Guilford Publisihing.

Loveland, E. (2017). Instant generation. The Journal of College Admission, 34-38.

Maftei, A., \& Enea, V. (2020). Symptoms of internet gaming disorder and parenting styles in Romanian adolescents. PSIHOLOGIJA, 53(3), 307-318. doi:https://doi.org/10.2298/PSI190808008M

Mat Saleh, M. S., Mahbob, N. N., \& Baharudin, N. S. (2017). Overviev of "Generation Z" behavioural charachteristic and its effect towards hostel facility. International Journal of Real Estate Studies, 59-67.

McKinley, R. A., McIntire, L. K., \& Funke, M. A. (2011, June). Operator selection for unmanned aerial systems: Comparing video game players and pilots. Aviation, Space, and Environmental Medicine, 82(6), 635-642. doi:10.3357/ASEM.2958.2011 
Öner, K., \& Arslantaş, H. (2018). Internet addiction in high school students, affecting factors. J.M.B., 1, 38-49.

Patton, M. Q. (2005). Qualitative Research. John Wiley \& Sons, Ltd. doi:https://doi.org/10.1002/0470013192.bsa514

Prensky, M. (2001). Digital natives, digital immigrants part 2: Do they really think differently? On the Horizon, 2-6.

Rickes, P. C. (2016). Generations in flux: How Gen Z will continue to transform higher education space. Planning for Higher Education Journal, 21-45.

Schermelleh-Engel, K., Moosbrugger, H., \& Müller, H. (2003). Evaluating the fit of structural equation models: Tests of significance and descriptive goodness-of-fit measures. Methods of Psychological Research, 8(2), 23-74.

Seemiller, C., \& Grace, M. (2016). Genration Z goes to college. San Francisco: John Wiley \& Sons.

Simon, D., Kriston, L., Andreas, L., Spies, C., Scheibler, F., Wills, C., \& Härter, M. (2010, September). Confirmatory factor analysis and recommendations for improvement of the AutonomyPreference-Index (API). Health Expectations, 13(3), 234-243. doi:10.1111/j.13697625.2009.00584.x

Tabachknick, B. G., \& Fidell, L. S. (2001). Using multivariate statistics. Needham Heights: MA: Allyn \& Bacon.

The Green Crescent. (2018). https://www.yesilay.org.tr/tr/haberler/detay/dso-acikladi-online-oyunve-online-kumar-bagimliligi-bir-ruh-sagligi-problemi adresinden alındı

Twenge, J. M. (2017). iGen: Why today's super-connected kids are growing up less rebellious, more tolerant, less happy - and completely unprepared for adulthood. New York: NY: Atria Books.

van Rooji, A. J., Schoenmakers, T. M., Vermulst, A. A., van den Eijnden, R. J., \& van de Mheen, D. (2010). Online video game addiction: identification of addicted. Addiction, 106, 205-212. doi:doi:10.1111/j.1360-0443.2010.03104.x

Weinstein, A., Livny, A., \& Weizman, A. (2017, April). New developments in brain research of internet and gaming disorder. Neuroscience \& Biobehavioral Reviews, 75, 314-330. doi:https://doi.org/10.1016/j.neubiorev.2017.01.040

Widyanto, L., \& McMurran, M. (2004). The psychometric properties of the internet addiction test. Cyberpsychology \& Behavior, 449-456.

World Health Organization. (2018). ICD-11 / 6C51 Gaming disorder. Retrieved May 2019, from https://icd.who.int/browse11//-m/en\#/http://id.who.int/icd/entity/1448597234

Young, K. S. (1998). Internet addiction: The emergence of a new clinical disorder. CyberPsychology \& Behavior, 237-244. 